\title{
The Identification of Individuals with Hatchery and Natural Origin in a Mixed Sample of Amur River Chum Salmon by Otolith Microchemistry
}

\section{Pavel B. Mikheev ${ }^{1,2}$, Denis V. Kotsyuk ${ }^{1}$, Elena V. Podorozhnyuk ${ }^{1}$, Vsevolod N. Koshelev ${ }^{1}$, Tatiana A. Sheina ${ }^{2}$, Mikhail A. Baklanov ${ }^{2}$ and Alexey Yu. Puzik ${ }^{2}$}

${ }^{I}$ Khabarovsk branch of the Federal State Budget Scientific Institution, Russian Federal Research Institute of Fisheries and Oceanography (KhabarovskNIRO), 13a Amurskij bul'var, Khabarovsk, Russia, 680038

${ }^{2}$ Perm State University (PSU), 15 Bukireva street, Perm, Russia

Keywords: otolith microchemistry, LA ICP-MS, chum salmon, identification of origin in a mixed sample, hatchery releases

Objective

This paper presents the results of using microchemical analysis of otoliths to identify chemical markers that are specific to juvenile fall chum salmon released from hatcheries in the Amur River basin, with their subsequent identification in otoliths of returning spawners. The implementation of this approach can be a methodological solution for detecting "hatchery-produced" and natural-origin fish in a mixed sample of chum salmon spawners.

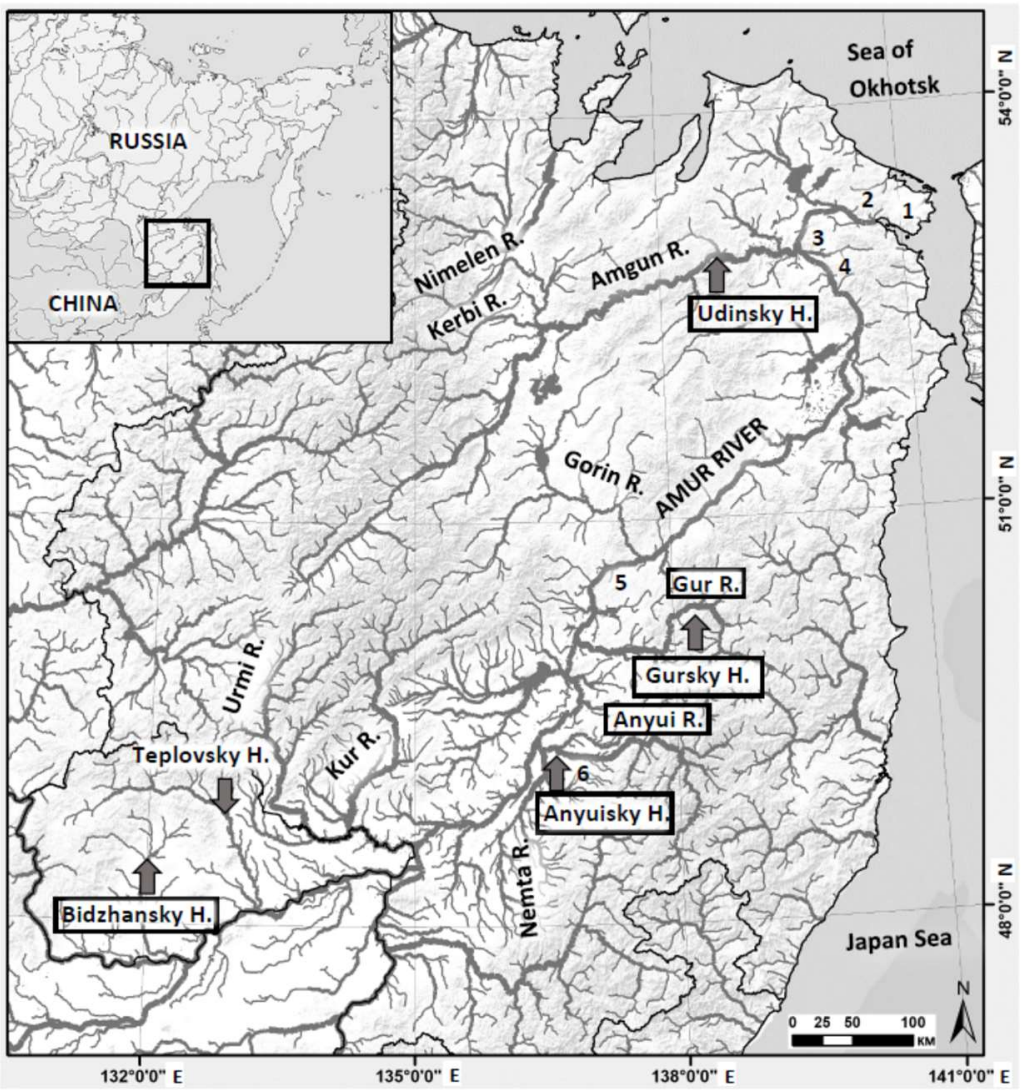

Fig. 1. Schematic map of collection sites for juveniles and spawners of fall chum salmon in the Amur River basin. The hatcheries and rivers where the juveniles were collected are highlighted by a frame. The collection sites for spawners of fall chum salmon are highlighted by numbers (1-Oremif Village, 2-Nikolaevsk-onAmur, 3-Tyr Village, 4-Susanino Village, 5-Belgo Village, 6-Anyuisky Hatchery).

It was hypothesised that the difference in the chemical composition of the edge zone of otoliths of hatcheryproduced juveniles and natural-origin juvenile fish, in terms of strontium ${ }^{88} \mathrm{Sr}$ to calcium ${ }^{43} \mathrm{Ca}$ isotopic ratio, would make it possible to establish fish origin. Analysis of strontium content in the juvenile zone of an otolith's thin section of an adult chum salmon was performed to test this hypothesis.

\section{Materials and methods}

This study used samples of juveniles and spawners of Amur River fall chum salmon.

Microchemical analysis was carried out at the Research Equipment Sharing Centre of the Geological Faculty of Perm State National Research University by laser ablation inductively coupled plasma mass spectrometry (LA ICP-MS) using LSX-213 G2 laser ablation system and a Bruker Aurora M90 — Quadrupole ICP-MS. 
The concentration of strontium ${ }^{88} \mathrm{Sr}$ and calcium ${ }^{43} \mathrm{Ca}$ isotopes in the edge zone of the otolith of juvenile fish were analysed at a distance of 152 to $229 \mu \mathrm{m}$ (on average $188.4 \pm 1.95 \mu \mathrm{m}$ ) from the primordia zone. We analysed the chemical composition of the juvenile zone of the otolith's thin section of adult fish at a distance of 159-205 $\mu \mathrm{m}$ (on average $183.2 \pm 1.13 \mu \mathrm{m}$ ) from the primordia.

The obtained absolute values of the ${ }^{88} \mathrm{Sr}$ isotope concentration (ppm) were standardized relative to the ${ }^{43} \mathrm{Ca}$ isotope concentration (\%) and presented as a ratio of molar masses.

\section{Results}

In most of the comparison pairs, fall chum salmon juveniles of artificial origin had high ${ }^{88} \mathrm{Sr} /{ }^{43} \mathrm{Ca}$ ratio values in the edge zone of otoliths compared with juvenile fish of natural origin. Pairwise, multiple comparisons of groups performed using the Tukey HSD test showed that juvenile fish of natural origin had significantly $(p<0.001)$ lower values of the studied indicator compared with juveniles collected at fish hatcheries; however, the sample taken from the Bidzhansky Hatchery in 2018 did not differ from juveniles sampled at the Gur River $(p=0.999)$ and the Anyui River in $2018(p=0.163)$, on 29 April $2020(p=0.839)$, and on 6 June $2020(p=0.098)$. Samples of juveniles of natural origin did not differ statistically from each other with the exception of one pair whose comparison with the $p$-value was close to the used significance level; juveniles from the Gur River had a higher ${ }^{88} \mathrm{Sr} /{ }^{43} \mathrm{Ca}$ ratio when compared with juveniles from the Anyui River, sampled on 17 June $2019(p=0.029)$. Among the hatchery-origin juveniles of fall chum salmon, the lowest ${ }^{88} \mathrm{Sr} /{ }^{43} \mathrm{Ca}$ ratio values were characteristic of the fish of the Bidzhansky Hatchery. Juveniles of the Gursky and Udinsky Hatcheries had the highest values of the analysed indicator which was shown at the most pairs of comparison following results of Tukey HSD test. Figure 2 shows box plot diagrams of the ${ }^{88} \mathrm{Sr} /{ }^{43} \mathrm{Ca}$ isotope ratio values of the edge zone of otoliths of juvenile fall chum salmon samples collected in 2018-2020 from hatcheries and the Gur and Anyui Rivers.

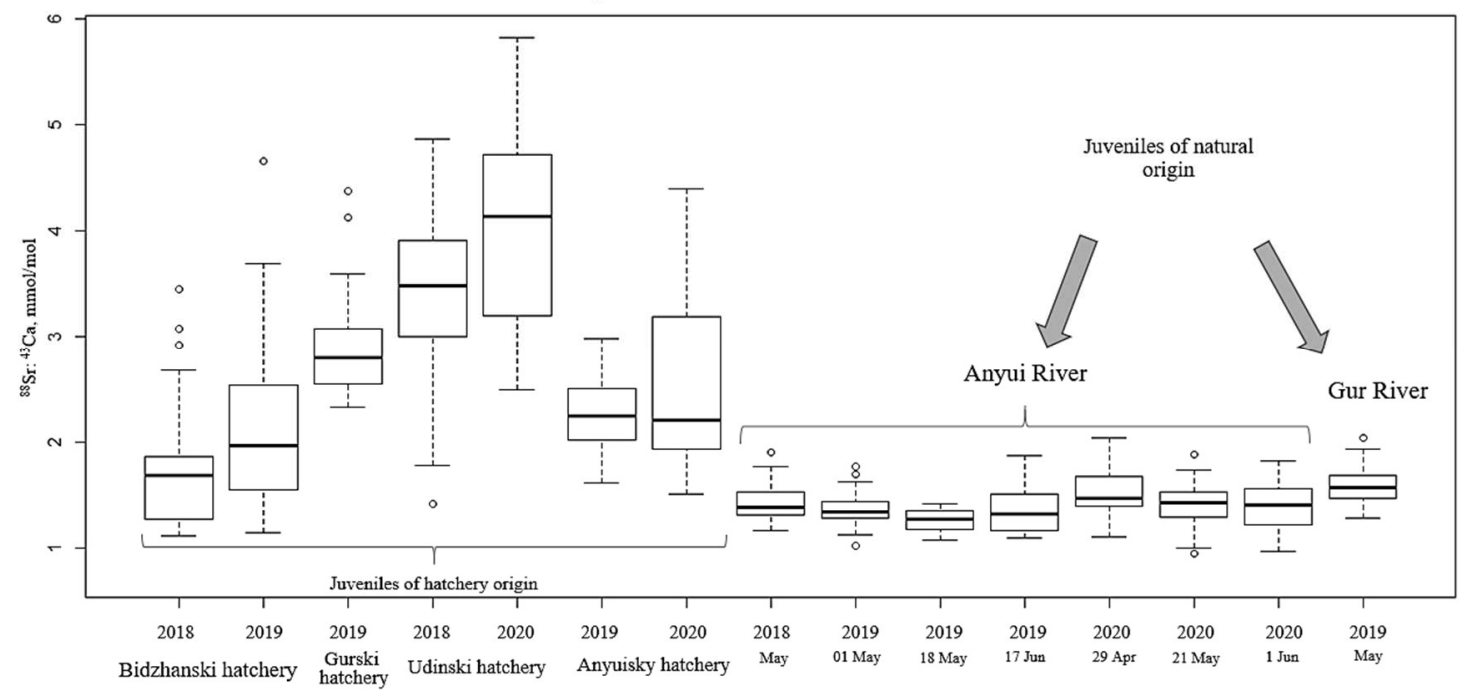

Fig. 2. Values of the ${ }^{88} \mathrm{Sr}:{ }^{43} \mathrm{Ca}$ isotope ratio of the edge zone of otoliths of juvenile fall chum salmon from Bidzhansky Hatchery, Gursky Hatchery, Udinsky Hatchery, Anyuisky Hatchery, the Anyui River, and the Gur River.

Fall chum salmon spawners collected at the Anyuisky Hatchery significantly differed from fish collected from catches at the main channel of the Amur River in terms of the ${ }^{88} \mathrm{Sr}:{ }^{43} \mathrm{Ca}$ isotope ratio value of the juvenile zone of otoliths (ANOVA, $F_{9.350}=180, p<0.001$ ). Both male and female fall chum salmon of the Anyuisky Hatchery had significantly higher values of the studied indicator in all comparison pairs, except for the sample collected at the mouth of the Amur River near Oremif Village ( $p=0.985$ for males, $p=0.803$ for females).

Among adult chum from the Amur River, the individuals captured at the start of spawning migration during 29 August- 5 September had a higher ${ }^{88} \mathrm{Sr}:{ }^{43} \mathrm{Ca}$ isotope ratio value of the juvenile zone of otoliths in comparison to individuals sampled during the second half of September. The adults captured at the mouth of the Amur River near Oremif Village had higher values of the ${ }^{88} \mathrm{Sr} /{ }^{43} \mathrm{Ca}$ ratio in comparison with other fish collected in the Amur River main channel, the exception being fish captured near Nikolaevsk-on-Amur on 3 September $(p=0.081)$ and 5 September $(p=0.106)$. Figure 3 shows box plot diagrams of the ${ }^{88} \mathrm{Sr} /{ }^{43} \mathrm{Ca}$ isotope ratio values of the juvenile zone of otoliths of fall chum salmon spawners samples from the Anyuisky Hatchery and the Amur River collected in 2019 . 


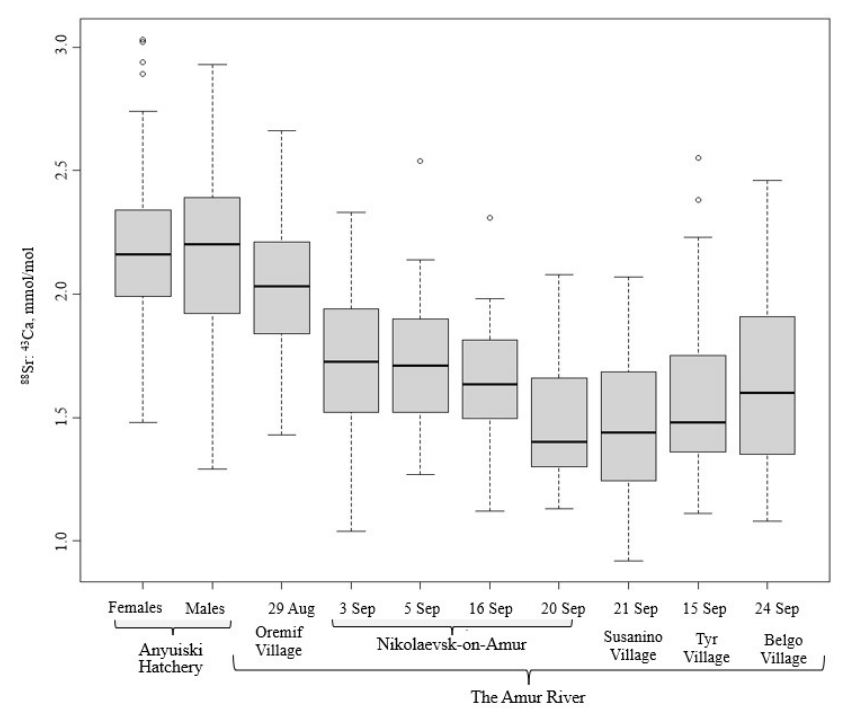

Fig. 3. Values of the ${ }^{88} \mathrm{Sr}:{ }^{43} \mathrm{Ca}$ isotope ratio of the juvenile zone of otoliths of fall chum salmon spawners samples from the Anyuisky Hatchery and the Amur River collected in 2019.

Table 1. The proportion of fish with the ${ }^{88} \mathrm{Sr}:{ }^{43} \mathrm{Ca}$ molar ratio value higher than $1.7 \times 10^{-3}$ among samples of the Amur fall chum salmon spawners used in the study.

\begin{tabular}{cccc}
\hline Sampling site & Sampling date & $\begin{array}{c}\text { Number of } \\
\text { specimens processed } \\
\text { by LA ICP-MS }\end{array}$ & $\begin{array}{c}\text { Proportion of fish with the } \\
\text { marker value higher than } \\
1.7 \times 10^{-3}, \%\end{array}$ \\
\hline Anyuisky Hatchery (males) & 30 Sep-5 Oct 2019 & 85 & 84 \\
Anyuisky Hatchery (females) & & 101 & 95 \\
The Amur River, Oremif Village & 29 Aug 2019 & 18 & 89 \\
& 3 Sep 2019 & 26 & 54 \\
The Amur River, Nikolaevsk-on-Amur & 5 Sep 2019 & 22 & 50 \\
& 16 Sep 2019 & 20 & 35 \\
The Amur River, Tyr Village & 20 Sep 2019 & 13 & 15 \\
The Amur River, Susanino Village & 15 Sep 2019 & 14 & 36 \\
The Amur River, Belgo Village & 21 Sep 2019 & 24 & 17 \\
\hline
\end{tabular}

Based on the consistently low marker value in juveniles of natural origin, we used the upper threshold value of the $95 \%$ confidence interval for the ${ }^{88} \mathrm{Sr}:{ }^{43} \mathrm{Ca}$ molar ratio of these samples, which is equal to $1.7 \times 10 \mathrm{mmol} / \mathrm{mol}$, as a cut-off value to differentiate fish of artificial and natural origin. With this approach, the distribution of the studied adults over the variational series of values of the analysed marker allows us to assume the ratio of natural- and artificial-origin individuals among the studied spawners. Among fish from the Anyuisky Hatchery, most of the fish have marker values higher than the threshold level we have accepted. Moreover, the proportion of such fish is higher among females than males. Also, a comparatively high proportion of such fish was found among 18 specimens of fall chum salmon collected in late August at the mouth of the Amur River. Fish with high strontium content in the juvenile zone of otoliths were most rare in catches in the last 10 days of September (Table 1).

Table 2. The number of fish by age group of adult fall chum salmon from the Anyuisky Hatchery and the Amur River main channel with different values of the analysed isotopic ratio of the juvenile zone of the otolith.

\begin{tabular}{cccc}
\hline \multirow{2}{*}{ Age } & \multicolumn{2}{c}{ Fish from the Amur River main channel } & Anyuisky Hatchery \\
\cline { 2 - 4 } & ${ }^{88} \mathrm{Sr}:{ }^{43} \mathrm{Ca}<1.7 \mathrm{mmol} / \mathrm{mol}$ & ${ }^{88} \mathrm{Sr}:{ }^{43} \mathrm{Ca}>1.7 \mathrm{mmol} / \mathrm{mol}$ & ${ }^{88} \mathrm{Sr}:{ }^{43} \mathrm{Ca}>1.7 \mathrm{mmol} / \mathrm{mol}$ \\
\hline $2+$ & 32 & 27 & 2 \\
$3+$ & 62 & 40 & 82 \\
$4+$ & 5 & 1 & 74 \\
$5+$ & & & 1 \\
\hline
\end{tabular}


The age structure of fall chum salmon collected at the Amur River main channel differed from that at the Anyuisky Hatchery (Table 2). Among the Amur River individuals with a ${ }^{88} \mathrm{Sr}:{ }^{43} \mathrm{Ca}$ molar ratio value below $1.7 \times 10^{-3}$, fish aged $4+$ were the largest proportion $(63 \%)$ and fish aged $3+$ had the lowest proportion (33\%). Individuals with the chemical marker value higher than $1.7 \times 10 \mathrm{mmol} / \mathrm{mol}$ were proportioned differently: $4+$ fish was somewhat lower (59\%) and $3+$ fish was slightly higher (40\%). Among the fish collected at the Anyuisky Hatchery with a ${ }^{88} \mathrm{Sr}:{ }^{43} \mathrm{Ca}$ marker value higher than $1.7 \times 10 \mathrm{mmol} / \mathrm{mol}, 3+$ individuals were numerically predominate. In a mixed-sex sample of fish, the proportion of individuals aged $3+$ was $52 \%$, the proportion of fish aged $4+$ was $45 \%$. Also, among the fish collected at the Anyuisky Hatchery, two fish aged 2+ were present, while the fish captured in the Amur River main channel such specimens were not found. The proportion of occurrence of fish aged 5+ was the highest (5\%) among the Amur River individuals with a ${ }^{88} \mathrm{Sr}:{ }^{43} \mathrm{Ca}$ value below the threshold level we used.

\section{Conclusion}

The results of this study may indicate the applicability of our approach to the determination of artificial-origin fish in a mixed sample of Amur fall chum salmon. The following results may serve as evidence of the applicability of the method used for the stated purpose: the revealed ratio of artificial- and natural-origin fish among Anyuisky Hatchery fish, the proportion of "hatchery-produced" fish among females and males of fall chum salmon collected at the Anyuisky Hatchery, and age composition and phenological shift in spawning migration time of the fish classified as fish of artificial origin. Results similar to ours were obtained for the chum salmon of Alaska, Kamchatka, the Kuril Islands, and Hokkaido Island (Imai et al. 2007; Zaporozhets and Zaporozhets 2012; McConnell et al. 2018; Knudsen et al. 2021).

\section{REFERENCES}

Imai, N., Y. Sagawa, H. Kudo, and M. Kaeriyama. 2007. A comparison of secondary sexual characters and age composition of wild and hatchery chum salmon (Oncorhynchus keta) in the Yarappu River, southern Hokkaido in Japan. N. Pac. Anadr. Fish Comm. Tech. Rep. 7: 115-116. (Available at https://npafc.org)

Knudsen, E.E., P.S. Rand, K.B. Gorman, D.R. Bernard, and W.D. Templin. 2021. Hatchery - origin stray rates and total run characteristics for pink salmon and chum salmon returning to Prince William Sound, Alaska, in 2013-2015. Mar. Coast. Fish. 13: 58-85. doi.org/10.1002/mcf2.10134.

McConnell, C., P. Westley, and M. McPhee. 2018. Differences in fitness-associated traits between hatchery and wild chum salmon despite long-term immigration by strays. Aquac. Environ. Interact. 10: 99-113. doi.org/10.3354/aei00261.

Zaporozhets, O.M, and G.V. Zaporozhets. 2012. Some consequences of Pacific salmon hatchery production in Kamchatka: changes in age structure and contributions to natural spawning populations. Environ. Biol. Fish. 94: 219-230. 